\title{
BIPOLAR TRANSURETHRAL RESECTION OF PROSTATE VERSUS OPEN PROSTATECTOMY IN PATIENTS WITH PROSTATIC VOLUMES FROM 80- 120 GM: A PROSPECTIVE RANDOMIZED STUDY.
}

\author{
By
Ahmed Abdullah Al-Refaey, Sabri Mahmoud Khaled, Ibrahim Alaa El- Din Tagrida, and Ahmed Gamal El-Din Abd El-Raouf

Department of Urology, Al-Azhar Faculty of Medicine, Cairo, Egypt

Corresponding author: Ahmed Abdullah Al-Refaey, Mobile: +201149394121,

E-mail: ahmedrefa3y1312@yahoo.com

\begin{abstract}
Background: Transurethral resection of the prostate (TURP) is still considered the gold standard in the treatment of benign prostatic hyperplasia (BPH). However, open prostatectomy is indicated for prostate glands over $80 \mathrm{ml}$. There have been few reports concerning the use of TURP for large prostate glands over $100 \mathrm{ml}$.

Objective: To prospectively compare the effectiveness and safety of bipolar TURP and open prostatectomy in prostate glands ranging from $80-120 \mathrm{ml}$.

Patients and Methods: We reviewed the data of 60 patients with prostate glands ranging from $80-120 \mathrm{ml}$. which were randomized 30 patients underwent bipolar TURP (group A), and another 30 underwent open prostatectomy (group B). Preoperative International Prostate Symptom Score (IPSS), flow rate (Qmax), prostate volume, resected tissue volume, and operative time were documented. Postoperative hemoglobin, serum sodium change, hospital stay, duration of catheter indwelling and postoperative 6-month IPSS and Qmax were evaluated.
\end{abstract}

Results: The Bipolar TURP (B-TURP) and open prostatectomy (OP) emphasized similar mean operating durations as well as the mean hemoglobin drop, catheterization period and hospital stay were significantly improved for bipolar group. During the follow up period, no statistically significant difference was determined in terms of IPSS, Qmax, QOL, PVRU between the two series.

Conclusion: Bipolar TURP represented a promising endoscopic approach in very large BPH cases compared with standard open prostatectomy as patients benefited from significantly satisfactory follow up symptom scores and voiding parameters.

Keywords: Bipolar transurethral resection of the prostate, open prostatectomy, large prostate

\section{INTRODUCTION}

$\mathrm{BPH}$ can lead to enlargement of the size of prostate BPE (benign prostatic enlargement). This enlargement can lead to obstruction at the level of bladder neck. BOO (bladder outlet obstruction) may be caused by other conditions. Parallel to these anatomical and functional processes, LUTS (lower urinary tract symptoms) occurs. LUTS increase in frequency and severity with age. LUTS can be caused by a variety of conditions. LUTS secondary to $\mathrm{BPH}$ is the target of intervention (Foster et al., 2018). 
For those with small and medium sized prostates $(30-80 \mathrm{~mL})$, monopolar transurethral resection of the prostate (MTURP) is still the gold standard operation for managing moderate-to-severe lower urinary tract symptoms (LUTS) secondary of benign prostatic obstruction (BPO), despite the introduction of newer safer alternative procedures. Although excellent results have been reported for M-TURP, some patients with high risk of bleeding, comorbidities, or big prostates are not considered candidates (Zou et al., 2018).

However, the safety and efficacy of TURP is mainly shown on treating small or medium prostates. Complications associated with this procedure are still significant in patients with larger prostates and include blood loss, capsular perforation, transurethral resection syndrome, and incontinence. Therefore, an increasing number of variant endoscopic techniques have been introduced and become the new reference standard for treating BPH (WU et al., 2016).

The present work aimed to evaluate the efficacy and safety of bipolar TURP for treating large prostate volumes up to 120 $\mathrm{g}$ and comparing the outcome with the standard prostatectomy.

\section{PATIENTS AND METHODS}

This study was carried out at the Urology department of AL-Alazhar University Hospitals during the period from June 2017 to June 2019 with the aim of evaluating the safety and efficacy of bipolar transurethral resection of the prostate in comparison with open prostatectomy in large prostate between $80 \mathrm{gm}$ to $120 \mathrm{gm}$. Our study was approved by the local ethics and research committee and all participants provided an informed written consent before inclusion.

\section{Inclusion criteria:}

Patients with severe lower urinary tract symptoms (LUTS) according to IPSS $>18$, $\mathrm{Q} \max \leq 10 \mathrm{ml} / \mathrm{second}$, refractory urinary retention, recurrent significant hematuria related to $\mathrm{BPH}$ and renal insufficiency due to $\mathrm{BOO}$ caused by BPH.

\section{Exclusion criteria:}

Abnormal coagulation profile, previous prostatic or urethral surgery, confirmed prostate cancer, neurogenic bladder dysfunction or sphincteric dyssenergia and prostate size more than $120 \mathrm{cc}$.

Parallel randomization was conducted at a ratio of $1: 1$, stratified by site, and was carried out using computer generated random numbers for Patients whose fulfilling criteria of the study and divided to 2 groups. Preoperative evaluation included the following: Detailed medical history, International prostate symptoms score (IPSS-0/35), quality of life bothersome score (0/6), full Physical examination, local examination (penis, scrotum \& DRE), focused neurologic examination, laboratory tests which include: urinalysis, culture and sensitivity tests, fasting blood sugar, serum electrolytes (sodium), complete blood count, prothrombin time, prothrombin concentration and INR, PSA (Total \& free), uroflowmetry test and imaging tools: ultrasound of the abdomen and pelvis with measurement of post voiding residual urine and transrectal ultrasound and biopsy was done if total PSA was $>4$ $\mathrm{ng} / \mathrm{dl}$. 


\section{Surgical procedures:}

Standard open prostatectomy was done using transvesical or retropubic approaches. As regard to bipolar TURP: Diagnostic urethrocystoscopy was done for evaluating prostate size and any intravesical abnormality i.e bladder mass, stone bladder. Bipolar TURP was performed using isotonic $0.9 \%$ sodium chloride irrigation solution, using a Karl Storz 26Fr continuous resectoscope with bipolar electrode using the bipolar current with $200 \mathrm{~W}$ cutting and $75 \mathrm{~W}$ coagulation power. Typically, the median lobe is resected down to the point where circular bladder neck fibers are encountered. Once the median lobe has been resected appropriately, the resection continues in the floor of the prostate to the proximal aspect of the verumontanum. The verumontanum is the key landmark used during resection of the prostate and should not be respected. The procedure starts with the ventral parts of the gland (between 11 and 1 o'clock), followed by both lateral lobes and finishing with the apex. At the end of the procedure a $22 \mathrm{Fr}$ 3-way Foley catheter with a closed drainage system was inserted. All patients were treated postoperatively with continuous saline bladder irrigation until the efflux was sufficiently clear.

All patients were intraoperatively observed for the following parameters: Operative time, estimated blood loss, blood transfusion if needed (when $\mathrm{Hb} \%$ dropped $<9 \mathrm{gm} / \mathrm{dl}$ or hemodynamics were affected as assessed by the anaesthetist) and the amount of blood transfusion (units), capsular perforation and volume of irrigant. Perioperative measured parameters included drop in hemoglobin and sodium levels, postoperative irrigation time, catheterization time and hospital stay time. Intraoperative and postoperative complications were documented using the modified Clavian Dindo system. All the patients were re-evaluated at 1,3 and 6 months postoperatively. At each point, IPSS, QOL, Qmax, PVRU, and adverse events were assessed.

The collected data were organized, tabulated and statistically analyzed using the Statistical Package for Social Science (SPSS) version 25 software. (IBM, Armonk, New York, United states).

Numerical data was summarized as means and standard deviations. Categorical data was summarized as numbers and percentages. General characteristics were compared between both groups using independent $t$ test for numerical data. Chi-square test was used for categorical data. Clinical and laboratory findings were compared preoperatively, 1, 3 and at 6 months using paired $t$ test or Wilcoxon signed ranks test for normally and non-normally distributed numerical data respectively. Percent change in clinical and laboratory findings were compared between both groups using Mann Whitney $U$ test. Repeated measures ANOVA tests for whether there are any differences between related means. Blood transfusion and complications were compared using Fisher's exact test. All $\mathrm{P}$ values were two sided. $\mathrm{P}$ values less than 0.05 were considered significant. 


\section{RESULTS}

Our study included 60 patients. Patients divided into two groups: Group (A) included 30 patients and group (B) included 30 patients. The two study arms emphasized similar preoperative parameters. There was no difference in patient age between the groups $(64.30 \pm 5.87$ vs $68.37 \pm 6.17)$ years, $P$ 0.113). Similarly, there was no significant difference in the prostatic volume by trans rectal ultrasonography $(109.73 \pm 7.45$ vs 113.90 \pm 6.13$) \mathrm{mL},(\mathrm{P}>0.097)$, hemoglobin $(13.10 \pm 0.80$ vs $13.14 \pm 1.09) \mathrm{g} / \mathrm{dl}, \quad(\mathrm{P}$ $0.291)$, and the total PSA $(5.07 \pm 2.57$ vs 4.59 \pm 3.00$) \mathrm{ng} / \mathrm{dl}$ (P 0.513) in the 2 groups, also the preoperative mean of IPSS, QoL, Qmax and PVRU showed no significant difference (Table1).

\section{Table (1): Preoperative parameters of the study groups}

\begin{tabular}{|c|c|c|c|}
\hline $\begin{array}{ll}\text { Parameters } & \text { Groups } \\
\end{array}$ & $\begin{array}{c}\text { Group A } \\
(\mathbf{n}=\mathbf{3 0})\end{array}$ & $\begin{array}{c}\text { Group B } \\
(\mathbf{n}=\mathbf{3 0})\end{array}$ & p-value \\
\hline \multicolumn{4}{|l|}{ Age (years) } \\
\hline Mean \pm SD & $64.30 \pm 5.87$ & $68.37 \pm 6.17$ & $>0.02$ \\
\hline \multicolumn{4}{|l|}{ Prostate volume $(\mathrm{ml})$} \\
\hline Mean \pm SD & $109.73 \pm 7.45$ & $113.90 \pm 6.13$ & $>0.03$ \\
\hline \multicolumn{4}{|l|}{ Hemoglobin (gm/dl) } \\
\hline Mean \pm SD & $13.10 \pm 0.80$ & $13.14 \pm 1.09$ & $>0.05$ \\
\hline \multicolumn{4}{|l|}{ PSA (ng/dl) } \\
\hline Mean \pm SD & $5.07 \pm 2.57$ & $4.59 \pm 3.00$ & $>0.05$ \\
\hline \multicolumn{4}{|l|}{ IPSS } \\
\hline Mean \pm SD & $23.37 \pm 2.97$ & $25.33 \pm 4.41$ & $>0.05$ \\
\hline \multicolumn{4}{|l|}{ QOL } \\
\hline Mean \pm SD & $5.57 \pm 0.68$ & $5.33 \pm 0.80$ & $>0.05$ \\
\hline \multicolumn{4}{|l|}{ PVRU } \\
\hline Mean \pm SD & $191.47 \pm 32.04$ & $186.23 \pm 30.20$ & $>0.05$ \\
\hline \multicolumn{4}{|l|}{ Qmax } \\
\hline Mean \pm SD & $9.02 \pm 1.40$ & $9.07 \pm 1.86$ & $>0.05$ \\
\hline
\end{tabular}

As regard to the perioperative data, there was no significant difference between the mean operative time of both groups which was calculated in minutes in the bipolar group from the diagnostic cystoscopy till the end of the resection, while in the open group, it is calculated from the opening of the skin till the closure after removal of the adenoma., (97.17 \pm 11.38 vs $91.57 \pm 12.03$ minutes), ( $\mathrm{P}$ $0.270)$. Two cases in the bipolar group and only one case in the OP group that have been complicated by perforation and treated conservatively. There was no significant difference between both groups as regard to the postoperative serum $\mathrm{Na}$ $(134.97 \pm 2.53$ vs $135.67 \pm 2.53) \mathrm{mEq} / \mathrm{l}(\mathrm{P}$ 0.326). The mean drops from base line in hemoglobin were significantly lower in the BTURP group than in the OP group $(11.55 \pm 1.02$ vs $10.94 \pm 0.80) \mathrm{gm} / \mathrm{dl}$, (P 0.027). As regard to the patients needed blood transfusion postoperative, there was no significant difference between both groups The postoperative bladder irrigation volume in patients undergoing BTURP $\quad(4666.67 \pm 1988.47) \mathrm{ml}$ was significantly less than that of patients who underwent OP $(6566.67 \pm 2473.07) \mathrm{ml}$, (P $<.01)$. Clot retention occurred in about $7 \%$ 
of cases of the bipolar group, and in about $14 \%$ of cases in the OP group with no significant difference $(\mathrm{P}>0.05)$. The mean time to removal of the catheter was significantly longer in the OP group $(8.43 \pm 1.36$ days $)$ than in the BTURP group $(2.87 \pm 0.63)$ days, $(\mathrm{P}<.001)$. Compared to OP $(5.83 \pm 1.18)$ days, the hospital stay was significantly shorter after BTURP $(1.63 \pm 1.01)$ days, $(\mathrm{P}<.001$, Table 2).

Table (2): Perioperative parameters of the study groups

\begin{tabular}{|c|c|c|c|}
\hline $\begin{array}{ll}\text { Parameters } & \text { Groups } \\
\end{array}$ & $\begin{array}{c}\text { Group A } \\
(\mathbf{n}=\mathbf{3 0})\end{array}$ & $\begin{array}{c}\text { Group B } \\
(\mathbf{n}=\mathbf{3 0})\end{array}$ & p-value \\
\hline \multicolumn{4}{|l|}{ Operative time (minutes) } \\
\hline Mean \pm SD & $97.17 \pm 11.38$ & $91.57 \pm 12.03$ & $>0.05$ \\
\hline \multicolumn{4}{|l|}{$\operatorname{Serum~Na(mEq/l)}$} \\
\hline Mean \pm SD & $134.97 \pm 2.53$ & $135.67 \pm 2.53$ & $>0.05$ \\
\hline \multicolumn{4}{|l|}{ Hemoglobin (gm/dl) } \\
\hline Mean \pm SD & $11.55 \pm 1.02$ & $10.94 \pm 0.80$ & $<0.02$ \\
\hline \multicolumn{4}{|l|}{ Perforation } \\
\hline Yes & $2(6.7 \%)$ & $1(3.3 \%)$ & $>0.05$ \\
\hline No & $28(93.3 \%)$ & $29(96.7 \%)$ & $>0.05$ \\
\hline \multicolumn{4}{|l|}{ Blood transfusion } \\
\hline 1 unite(Packed RBC) & $3(10.0 \%)$ & $4(16.9 \%)$ & \multirow{2}{*}{$>0.05$} \\
\hline 2 unites (Packed RBC) & $0(0.0 \%)$ & $2(6.7 \%)$ & \\
\hline \multicolumn{4}{|c|}{ Volume of continuous irrigation (cc) } \\
\hline Mean \pm SD & $4666.67 \pm 1988.47$ & $6566.67 \pm 2473.07$ & $<0.01$ \\
\hline \multicolumn{4}{|l|}{ Clot retention } \\
\hline Yes & $2(6.7 \%)$ & $4(14.7 \%)$ & $>0.05$ \\
\hline No & $28(93.3 \%)$ & $24(86.3 \%)$ & $>0.05$ \\
\hline \multicolumn{4}{|l|}{ Catheter time (days) } \\
\hline Mean \pm SD & $2.87 \pm 0.63$ & $8.43 \pm 1.36$ & $<0.001$ \\
\hline \multicolumn{4}{|l|}{ Hospital stay (days) } \\
\hline Range & $1.63(1-3)$ & $5.83(4-8)$ & $<0.001$ \\
\hline
\end{tabular}

At the 1, 3 and 6- month follow-ups, compared with baseline, there were significant improvements in IPSS, QOL, Qmax and PVRU and in both groups after surgery. No significant difference was found between the groups in IPSS, QOL, Qmax and PVRU (Table 3). 
AHMED ABDULLAH AL-REFAEY et al.,

Table (3): Follow up according to QOL, IPSS, Q.Max and PVRU between both groups

\begin{tabular}{|c|c|c|c|c|c|c|}
\hline Item & Groups & $\begin{array}{c}\text { Pre- } \\
\text { operative }\end{array}$ & $\begin{array}{l}\text { After } 1 \\
\text { month }\end{array}$ & $\begin{array}{l}\text { After } 3 \\
\text { month }\end{array}$ & $\begin{array}{c}\text { After } 6 \\
\text { month }\end{array}$ & p-value \\
\hline \multirow{2}{*}{ QOL } & $\begin{array}{c}\text { Group A } \\
(\mathbf{n}=\mathbf{3 0})\end{array}$ & $5.57 \pm 0.68$ & $2.17 \pm 0.75$ & $2.05 \pm 0.75$ & $1.97 \pm 1.00$ & \multirow{2}{*}{$<0.001 * *$} \\
\hline & $\begin{array}{c}\text { Group B } \\
(\mathrm{n}=\mathbf{3 0})\end{array}$ & $5.33 \pm 0.80$ & $2.53 \pm 0.90$ & $2.23 \pm 0.90$ & $2.17 \pm 0.91$ & \\
\hline \multirow{2}{*}{ IPSS } & $\begin{array}{c}\text { Group A } \\
(\mathbf{n}=\mathbf{3 0})\end{array}$ & $23.37 \pm 2.97$ & $7.57 \pm 2.13$ & $5.00 \pm 3.29$ & $4.03 \pm 3.73$ & \multirow{2}{*}{$<0.001 * *$} \\
\hline & $\begin{array}{c}\text { Group B } \\
(\mathbf{n}=30)\end{array}$ & $25.33 \pm 4.41$ & $8.10 \pm 2.71$ & $6.60 \pm 3.19$ & $5.10 \pm 3.73$ & \\
\hline \multirow{2}{*}{ Q.Max } & $\begin{array}{c}\text { Group A } \\
(\mathbf{n}=\mathbf{3 0})\end{array}$ & $9.02 \pm 1.40$ & $17.05 \pm 1.70$ & $17.98 \pm 2.40$ & $17.67 \pm 2.51$ & \multirow{2}{*}{$<0.001 * *$} \\
\hline & $\begin{array}{c}\text { Group B } \\
(n=30)\end{array}$ & $9.07 \pm 1.86$ & $16.97 \pm 2.27$ & $18.83 \pm 3.03$ & $17.75 \pm 2.62$ & \\
\hline \multirow{2}{*}{ PVRU } & $\begin{array}{c}\text { Group A } \\
(\mathbf{n}=\mathbf{3 0})\end{array}$ & $\begin{array}{c}191.47 \\
(159-221)\end{array}$ & $23.10(10-57)$ & $24.64(14-43)$ & $25.90(8-48)$ & \multirow{2}{*}{$<0.001 * *$} \\
\hline & $\begin{array}{c}\text { Group B } \\
(\mathbf{n}=\mathbf{3 0})\end{array}$ & $\begin{array}{c}186.23 \\
(156-216)\end{array}$ & $32.17(15-68)$ & $28.22(10-58)$ & $38.67(16-37)$ & \\
\hline
\end{tabular}

Repeated Measurement ANOVA

$* * \mathrm{p}$-value $<0.001 \mathrm{HS}$

As regard to the complications in the bipolar group, there were 2 patients developed persistent LUTS post operatively and treated by anticholinergics and the symptoms were improved after one month, 1 patient recathetrized due to retention of urine and needed re cystoscopy with resection of remnant prostatic tissue, another 1 patient hospitalized due to secondary hemorrhage and received IV fluids, antibiotics and hemostatic drugs for 3 days without recatheterization or need for blood transfusion, while there were 2 patients developed urethral stenosis which were treated by visual internal urethrotomy
(VIU). In the open group, there were 2 patients needed blood transfusion postoperative, 3 patients developed persistent LUTS and treated by anticholinergics and the symptoms were improved after 6 weeks, 2 patients hospitalized due to secondary hemorrhage and received IV fluids, antibiotics and hemostatic drugs for 2 days without re-catheterization or need for blood transfusion, while there were 1 patient developed bladder neck contracture and treated by bladder neck incision (BNI). There was no statistically significant difference between groups(Table 4) 


\section{Table (4): Complications were classified according to Clavian Dindo classification as the following}

\begin{tabular}{|l|c|c|c|}
\hline Groups & $\begin{array}{c}\text { Group A } \\
(\mathbf{n = 3 0 )}\end{array}$ & $\begin{array}{c}\text { Group B } \\
(\mathbf{n = 3 0})\end{array}$ & $\begin{array}{c}\text { p- } \\
\text { value }\end{array}$ \\
\cline { 1 - 3 } $\begin{array}{l}\text { Re-hospitalization for 2ry Hemorrhage\% } \\
\text { (CDI) }\end{array}$ & $1(3.3)$ & $2(6.7)$ & \\
\cline { 1 - 3 } Re-catheterization for retention\% (CDII) & $1(3.3)$ & $0(0.0)$ & \multirow{2}{*}{$>0.05$} \\
\hline Blood transfusion (CDII) & $0(0.0)$ & $2(6.7)$ & \\
\cline { 1 - 3 } Persistent LUTS (CDII) & $2(6.7)$ & $3(10.0)$ & \\
\hline Bladder neck contracture (CDIII) & $0(0.0)$ & $1(3.3)$ & \\
\cline { 1 - 3 } Urethral stenosis (CDIII) & $2(6.7)$ & $0(0.0)$ & \\
\hline
\end{tabular}

\section{DISCUSSION}

Benign prostatic hyperplasia is considered one of the most common causes of lower urinary tract symptoms. It usually occurs in aging men, in about 60 $\%$ of men above 60 years and $80 \%$ of men over the age of 70 years. As a consequence of the increased number of aged population and improvement in diagnostic tools, the prevalence of $\mathrm{BPH}$ has increased (Xu et al., 2018). Medical treatment is considered the first line in managing BPH. Contemporary guidelines advocate surgery as the standard of care for symptomatic BPH for cases refractory to medical treatment or those associated with complication, where the choice of the appropriate surgical procedure depends on the prostate size (Elkoushy et al., 2016). Transurethral resection of the prostate (TURP) is still considered the reference standard for the surgical treatment of symptomatic benign prostatic hyperplasia (BPH) (Fayad et al., 2015). However, complications of classical TURP as bleeding have been broadly recognized by urologists. Moreover, intravasation of hypotonic fluids, e.g., distilled water, mannitol and glycine carries the risk of developing TUR syndrome with serious morbidity and mortality in large prostate (Bolgeri et al., 2012).
The use of irrigation fluid for transurethral procedures ideally should be isotonic, non-hemolytic, electrically inert, non-toxic, transparent, easy to be sterilized and also inexpensive. The most widely used irrigation fluids for TURP are $1.5 \%$ glycine and sterile water. The osmolality of $1.5 \%$ glycine is 230 $\mathrm{mOsm} / \mathrm{L}$, which is lower than the serum osmolality of $290 \mathrm{mOsm} / \mathrm{L}$, and can cause complications resulting in TUR syndrome (Ghanem et al., 2018). Bipolar resection is done by creation of an ionized plasma corona, using an axipolar electrode and electro-conductive solution (normal saline). The active and return electrodes of the loop bend in the same axis. The use of normal saline irrigation $(\mathrm{NaCl} 0.9 \%)$ instead of hypotonic solution decrease the overall morbidity associated with TURP and eliminate the risk of TUR syndrome associated with prolonged resection time. Also coagulation of blood vessels gives better hemostatic results (Abuelazayem et al., 2019). Open prostatectomy (OP) is considered the standard surgical option for large prostate (> 80gm). OP is usually associated with substantial perioperative complications and morbidity, including prolonged catheterization time and length of hospital stay (Herrman et al., 2010). 
In our study, $33.3 \%$ in the bipolar group were presented with urinary retention. Brathwaite et al. (2014) demonstrated that $23 \%$ of patients in the B-TURP group has presented with urinary retention. The higher incidence of patients presented with urinary retention in our study may be attributed to the late presentation of patients in our country due to social and economic factors.

In the bipolar group, we recorded longer operative time than the open group with no significant difference. Similarly, Rubiao et al. (2013) demonstrated that BTURP procedure was not faster than OP procedure. The open prostatectomy group recorded loss more blood than bipolar group with significant differences. Blood loss did not disrupt the procedures; conservative management was enough in all except $27 \%$ of cases that needed blood transfusion, and $10.0 \%$ in the B-TURP group compared to $23.6 \%$ in the OP group. In agreement with our results, Rubaio et al. (2013) reported that the difference of the blood transfusion rates between both groups did not demonstrate statistical significance.

In our study, the hospital stay in the bipolar group was shorter; it ranged between 1-3 days versus 4-8 days in the open group with high significant difference between both groups. In agreement with our results, Kwon et al. (2015) reported significantly shorter hospitalization in the bipolar TURP method. Postoperative hospital stays were $6.3 \pm 1.3$ days, and $12.0 \pm 2.9$ days, in the $\mathrm{B}$ TURP and the OP respectively. In our study, the duration of indwelling catheter in bipolar group was shorter ranged between 2-4 days, compared to 8-10 days in the open group with high significant difference between both groups. In Srivastava et al. (2016) catheterization time were significantly higher in OP than B-TURP $\quad(8.7 \pm 1.3$ vs $4.3 \pm 1.1)$ respectively.

As regard to the postoperative complications, the risk of TUR syndrome was abolished by the use of saline irrigation in bipolar TURP. Our study demonstrated that in bipolar group, the mean $\mathrm{Na}$ level has dropped by $2 \mathrm{mEq} / \mathrm{l}$, which was insignificant and none of the patients was complicated by TUR syndrome. Clot retention occurred in about $7 \%$ of cases of the bipolar group, and in about $14 \%$ of cases in the OP group with no significant difference. There were $7 \%$ of patients developed persistent LUTS (irritative) post operatively in the bipolar group compared to $10 \%$ of patients in the OP group. All were treated by anticholinergics and the symptoms were improved after 4-6 weeks. Moreover, 7\% of patients of the bipolar group developed urethral stenosis which were treated by visual internal urethrotomy (VIU) versus one patient developed bladder neck contracture and treated by bladder neck incision (BNI) in the OP group. Two cases in the bipolar group and only one case in the OP group that have been complicated by perforation and treated conservatively. In agreement with our results, Srivastava et al. (2016) stated that the complications in the first year were well acceptable. The short-term stricture rate in the groups were, 1.23 , and $1.9 \%$ for B-TRUP and OP respectively.

Data on efficacy had been measured by the impact of each technique on IPSS, QOL score as well as Qmax and PVRU, 
compared to baseline. These date were provided at follow- up periods ranging from 1 to 6 months. In this study, bipolar TURP was equivalent to Open Prostatectomy in improving IPSS score and Quality of life (QOL). Mohaved et al. (2019) showed that there was no significant difference between the BTRUP and OP groups in the mean score of IPSS and the urinary function score. Srivastava et al. (2016) showed that there was a significant improvement in outcomes (IPSS, QoL, Q-max and PVR) in all the groups as compared to baseline and that groups were compared with each other and no significant difference was found in outcomes, suggesting that procedures were successful for both large and very large glands.

The patients of bipolar group in our study showed improved mean Qmax by $17.05 \mathrm{ml} / \mathrm{sec}, 17.98 \mathrm{ml} / \mathrm{sec}$ and 17.67 $\mathrm{ml} / \mathrm{sec}$, at 1,3 and 6 months respectively. The patients of OP group in, showed improved mean Qmax by $16.97 \mathrm{ml} / \mathrm{sec}$, $18.83 \mathrm{ml} / \mathrm{sec}$ and $17.75 \mathrm{ml} / \mathrm{sec}$, at 1,3 and 6 months respectively. Reda et al. (2014) demonstrated Qmax improvement by a mean of $15.46 \mathrm{ml} / \mathrm{sec}, 12.12 \mathrm{ml} / \mathrm{sec}$ and $11.82 \mathrm{ml} / \mathrm{sec}$ at 1,3 and 6 months respectively in bipolar group, as well as, $11.08 \mathrm{ml} / \mathrm{sec}, \quad 19.92 \mathrm{ml} / \mathrm{sec}$ and $17.48 \mathrm{ml} / \mathrm{sec}$ at 1,3 and 6 months respectively in OP group.

In our study, the mean PVRU improved with high significance in the postoperative follow up ultrasound in both groups. In bipolar group, the mean PVRU was $43.10,24.64,25.9$ at 1, 3, 6 months respectively in comparison with the mean preoperative value $(191.74 .05 \mathrm{cc})$. In OP group, the mean PVRU was 32.17, 22.28,
38.67 at 1, 3, 6 months respectively in comparison with the mean preoperative value $(186.23 \mathrm{cc})$. Simforoosh et al. (2014) demonstrated that in patients who underwent TURP the mean PVRU has decreased by $85.9 \mathrm{ml}$ and $88.2 \mathrm{ml}$ at 3 and 6 months respectively.

\section{CONCLUSION}

B-TURP had equivalent efficacy to OP for patients with $\mathrm{BPH}$ and prostate volumes $\geq 80 \mathrm{~mL}$ in addition to shorter duration catheterization and of hospital stay and fewer complications. B-TRUP can be considered a dependable alternative for minimizing open surgery related morbidity while practically maintaining similar efficacy in large volume prostate.

\section{CONFLICT OF INTEREST}

None.

\section{REFERENCES}

1. Abuelazayem $T$, Salah $E$ and Badr $M$ (2019): Bipolar Transurethral Resection (BTURP) versus vaporization (B-TUVP) in management of benign prostatic hyperplasia. Int. J. Curr. Res. Med. Sci, 5(8):7-20.

2. Brathwaite $\mathbf{D}$, Hussain $\mathbf{Z}$ and Ghiblawi $\mathbf{S}$, (2014): A prospective, randomized trial comparing conventional transurethral prostate resection with plasmakinetic vaporization of the prostate. J Urol, 176:205-209.

3. Bolgeri M, Naji S, Sahai A, Anjum F, Madaan S, Sriprasad S and Dickinson I (2012): Bipolar transurethral resection of prostate: current status in the management of bladder outflow obstruction. Br J Med Surg Urol., 5: 105- 10.

4. Elkoushy $M$ and Elhilali $M$ (2016): Management of benign prostatic hyperplasia larger than $100 \mathrm{ml}$ : simple open enucleation versus transurethral laser prostatectomy. Current Urology Reports, 1; 17(6):44-48. 
5. Fayad AS, Elsheikh MG, Zakaria T, Elfottoh HA, Alsergany R, Elshenoufy A and Elghamarawy $\mathbf{H}$ (2015): Holmium laser enucleation of the prostate versus bipolar resection of the prostate: a prospective randomized study. "pros and cons". Urology., 86:1037e41.

6. Ghanem A, Ghanem S, Ghanem $K$ and Pindoria N (2018): The transurethral resection of the Prostate (TURP) syndrome and acute dilutional hyponatraemia $(\mathrm{HN})$ : A comprehensive literature review from first incidence in 1947 to disappearance in 2018. Global Journal of Urology and Nephrology, 1:7-12.

7. Gang $\mathbf{W}$, Hong $\mathrm{Z}$, Chao L, Cuidong $\mathrm{B}$, Shengsong $H$ and Denglong $W$ (2016): A comparative study of diode laser and plasmakinetic in transurethral enucleation of the prostate for treating large volume benign prostatic hyperplasia: a randomized clinical trial with 12-month follow-up, Epub., 31(4): 599-604.

8. Harris E, Michael J, Philipp D, Manhar C, Steven A, Tobias S, Lori B, Deborah J, Kellogg J, Claus G, Charles W, Timothy J and Kevin T (2018): Surgical Management of Lower Urinary Tract Symptoms Attributed to Benign Prostatic Hyperplasia: AUA Guideline. 200, 1-8.

9. Herrmann TR, Bach T, Imkamp F, Georgiou A, Burchardt $M$, Oelke $M$ and Gross A (2010): Laser enucleation of the prostate: Transurethral anatomical prostatectomy with laser support. World J Urol., 28: 45-51.

10. Kwon J, Lee J, Lee S, Choi $H$ and Moon H (2015): Comparison of effectiveness of monopolar and bipolar transurethral resection of the prostate and open prostatectomy in large benign prostatic hyperplasia. Korean $\mathbf{J}$ Urol., 52:269-73.

11. Movahed $S$ and Kalkali A (2019): Comparison outcomes of improved urinary function in patients with benign prostatic hyperplasia using two open prostatectomy surgery and transurethral resection of the prostate. Drug Invention Today.12 (2):243247.

12. Reda M, Yassen $M$ and Ragy Sh (2014): Comparative study between open prostatectomy and TURis. Journal Of Endourology 29 (3), 323-331.

13. Rubiao $O$, Xiangrong $D$, Wenjun $Y$, Xinghua W, Hui C and Keji X (2013): Transurethral enucleation and resection of the prostate vs transvesical prostatectomy for prostate volumes $>80 \mathrm{~mL}$ : a prospective randomized study. BJU., 112;239-245.

14. Simforoosh N, Abdi H, Kashi AH, Zare S, Tabibi A, Danesh A, Basiri A and Sayed AM (2014): Open prostatectomy versus bipolar transurethral resection of the prostate, where are we standing in the new era? A randomized controlled trial. Urol J., 7:262-9.

15. Srivastava A, Dhayal IR and Rai P (2016): Management of Large Prostate Gland in Men with Impaired Renal Function: Comparison of Safety, Efficacy and Outcomes of Monopolar, Bipolar Transurethral Resection and Open Prostatectomy. Urologia internationalis., 96(4):413-20.

16. Xu P, Xu A, Chen B, Zheng S, Xu Y, Li H, Shen $H$ and Liu C (2018): Bipolar transurethral enucleation and resection of the prostate: Whether it is ready to supersede TURP? Asian Journal of Urology., 1;5(1):4854.

17. Zhihui Z, Abai $X$, Shaobo $Z$, Binshen $C$, Yawen X, Hulin L, Chongyang D, Junhong Z, Jiasheng C, Chaoming L, Yiming W, Yubo G, Chaozhao $L$ and Chunxiao $L$ (2018): Dual-centre randomized-controlled trial comparing transurethral endoscopic enucleation of the prostate using diode laser vs. bipolar plasmakinetic for the treatment of LUTS secondary of benign prostate obstruction: 1-year follow-up results World Journal of Urology, 36(7): 1117-1126. 


\section{مدي فاعلية المنظار ثنائي القطبين في إستئصال البروستاتا ذات

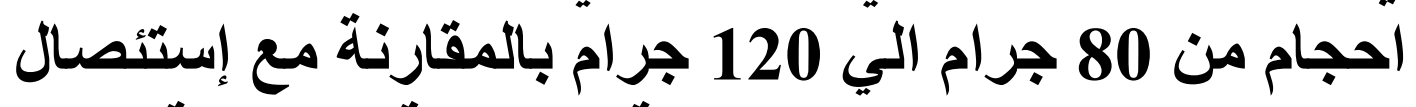

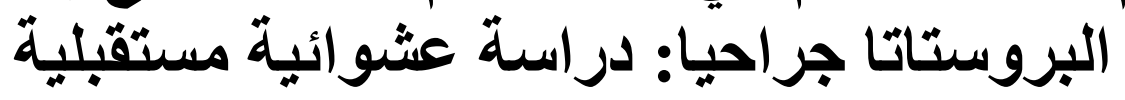

أحمد عبدالله الرفاعي، إبراهيم علاءالدين تجريدة، صبري محمود خالد، أحمد جمال

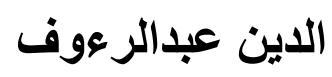

قسم جراحة المسالك البولية، كلية الطب، جامعة الأزهر، القاهرة، مصر

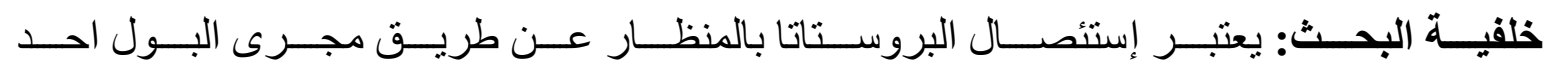

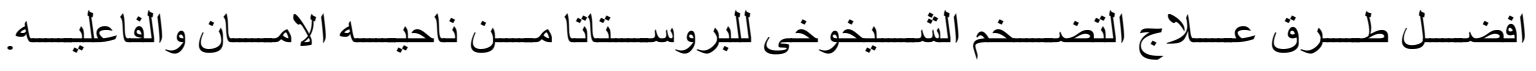

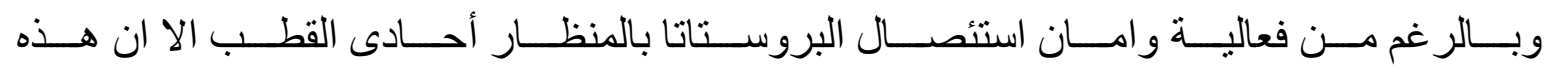

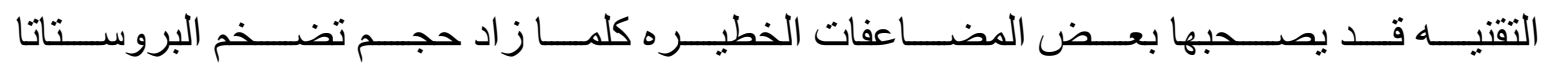

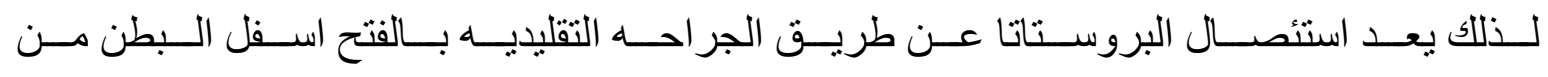

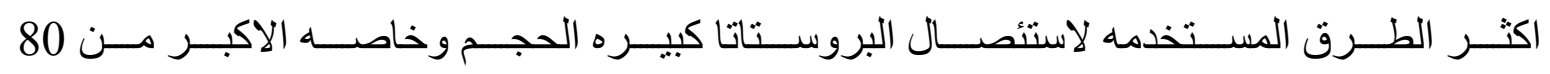

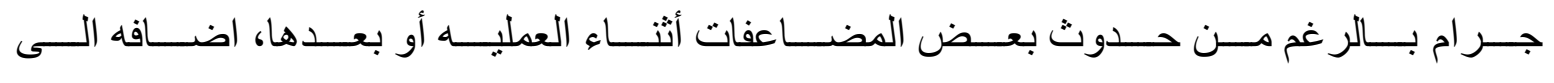

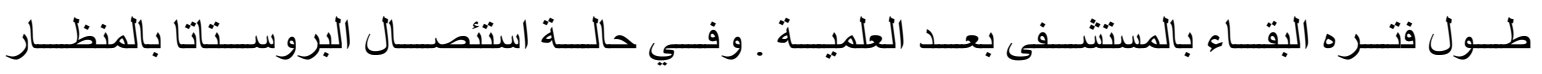

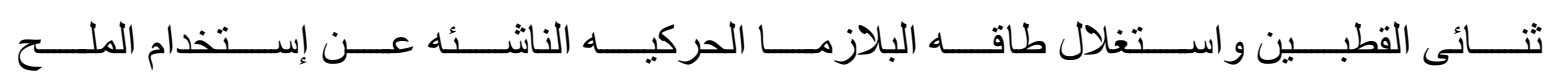
الجر احى، بالتالى يمكن العمل لفتر ات أطول دون التقييد بوقت.

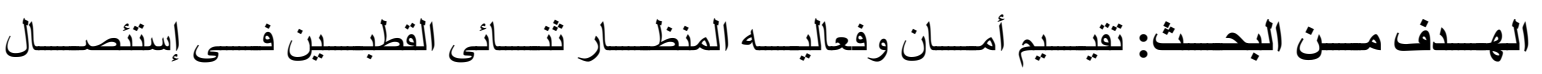
البروستاتا من 80 جر ام الي 120 جر ام مقارنة باستنئصالها جر احيا.

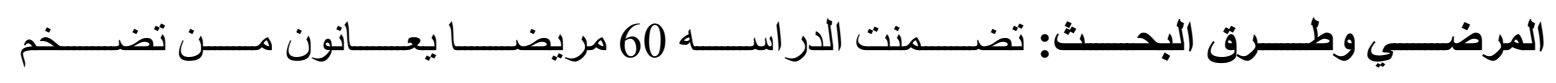

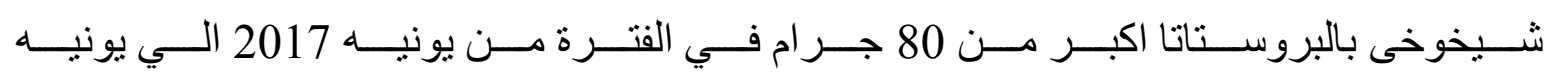
2019 وتم تقسيمهم الى مجمو عتين:

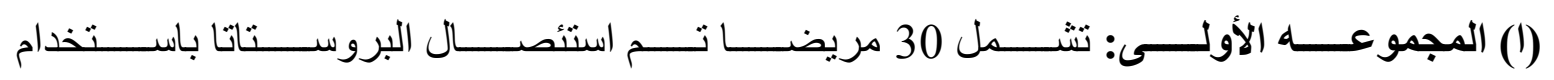
المنظار ثنائي القطبين.

(ب) المجموعه الثانيه: تشمل 30 مريضا تم إستثـال البروستاتا جر احيا. 


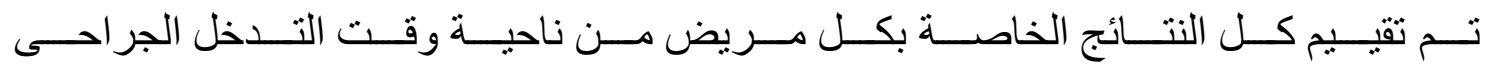

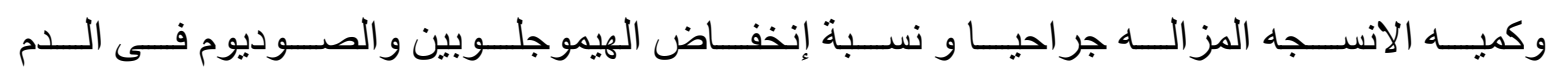

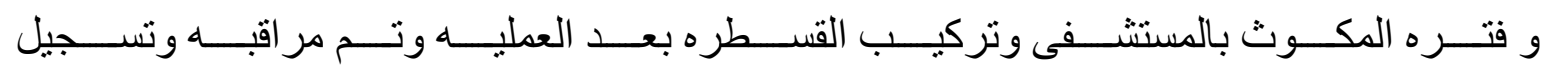

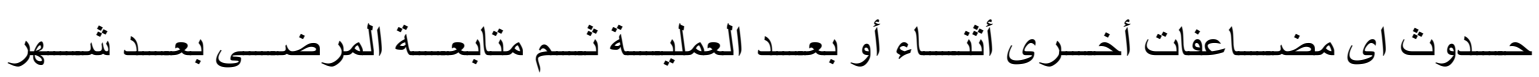

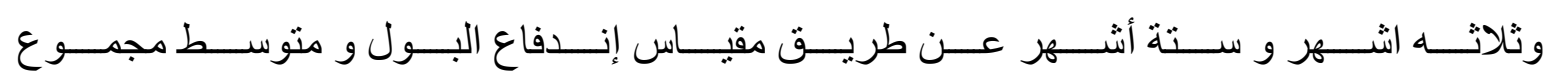

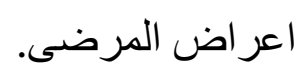

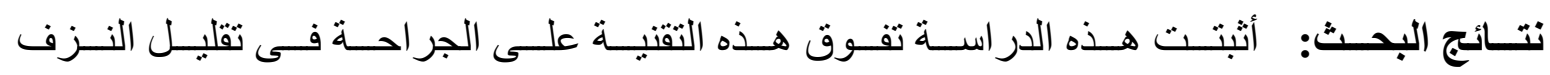

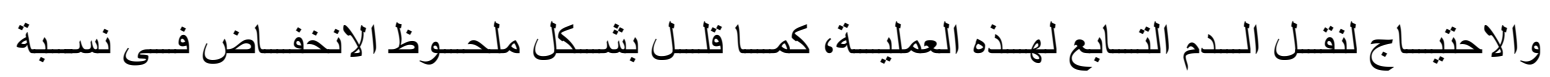

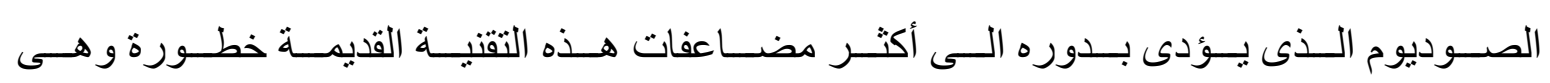

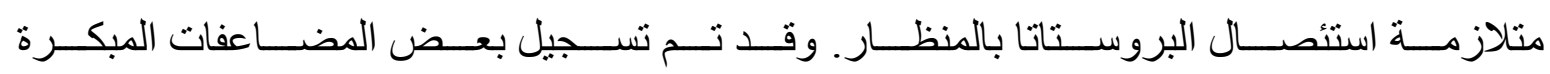

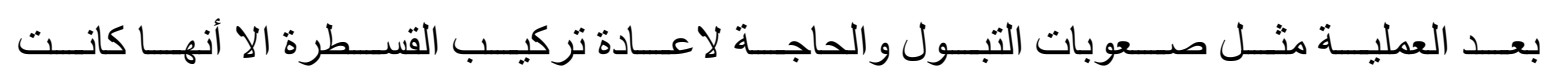

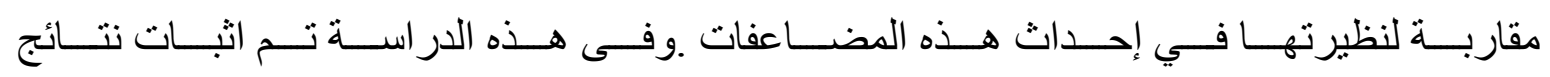

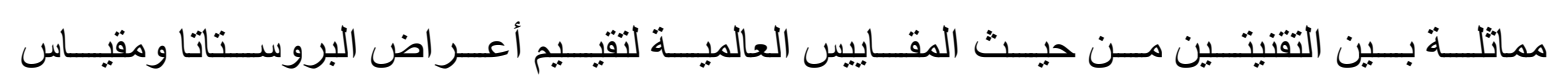

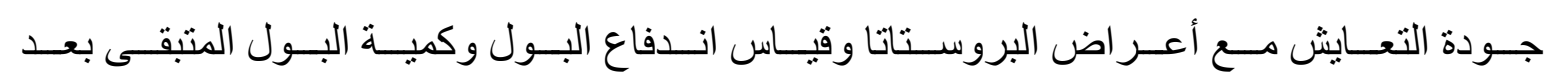
التبول فى خلال فتر ات المتابعة على شهر وثناثة أشهر وستة أشهر.

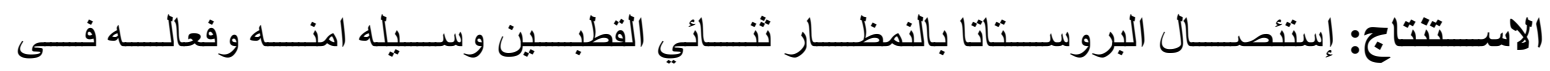

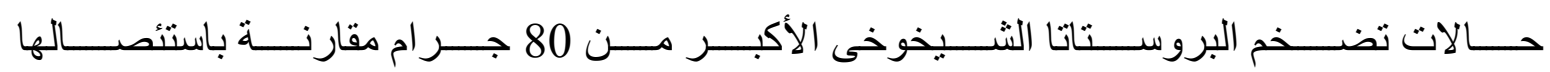
جر احيا.

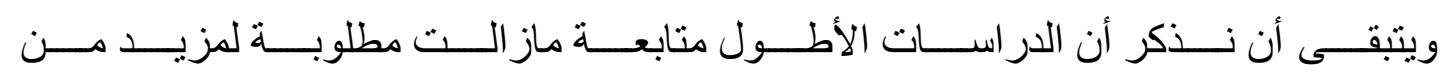

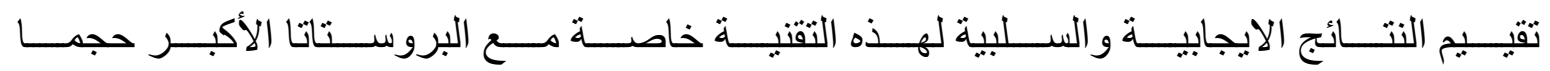

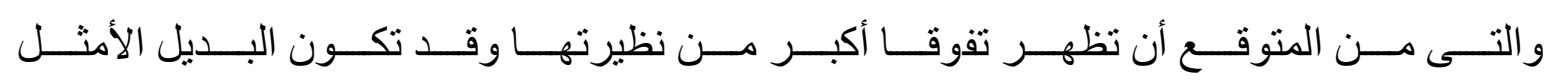
للاستئصال الجر احى للبروستاتا فى المستقبل. 